\title{
PROCEDURAL TRANSPARENCY IN THE SETTLEMENT OF TREATY-BASED INVESTMENT DISPUTES IN EVIPA AND CPTPP
}

\author{
HAI YEN TRINH* \\ International Law Faculty, the Diplomatic Academy of Vietnam \\ Email: trinh.h.yen@gmail.com \\ THE HOANG NGUYEN $\star \star$ \\ Vietnam International Law Firm (VILAF) \\ Email: hoang.nguyen@vilaf.com.vn
}

\section{Abstract}

Important characteristics of commercial arbitration include privacy and confidentiality; nonetheless, in investor-state arbitration, most of the investment treaties or arbitral rules referred therein often seek to enhance transparency and public participation by introducing three new features to investment arbitration's proceedings: public access to documents related to the arbitration, public access to hearings; and amicus curiae submission. Those provisions generally contain exceptions to maintain a balance between the public interest on the one hand, and the interest of the disputing parties on the other hand in the fair and efficient resolution of the dispute. The two treaties Viet Nam has recently concluded, the Comprehensive and Progressive Agreement for Trans-Pacific Partnership (CPTPP) and the EU-Viet Nam Investment Protection Agreement (EVIPA), have stipulated the procedural transparency requirements, which are in line with a new trend of development in international investment law. Although Viet Nam currently maintains confidentiality with regard to investor-state arbitration, the fact that Viet Nam has made international commitments on transparency promises benefits such as increasing public interest protection, improving governance and ensuring the right to information.

Keywords: transparency, investment treaties, investor-state arbitration, EVIPA, CPTPP

The resolution of disputes between investors and host states is a central issue of international investment law. The number of cases already handled and being handled by international arbitration in accordance with international treaties has reached nearly 942 cases in just 30 years an unprecedented number in any areas of international law. ${ }^{1}$ This signifies the great demand from investors to enjoy protection under international commitments and initiating claims in accordance with international mechanism, which is independent of the administrative and judicial bodies or domestic arbitration of the host states. At the same time, this international arbitration mechanism is facing several criticisms, one of which is its lack of transparency.

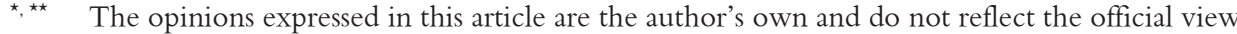
of the institution where the author works or any other institutions and organizations. UNCTAD, Fact sheet on investor-state dispute settlement cases in 2018, May 2019, p.1.
} 
Most of investment treaties ${ }^{2}$ to which Viet Nam is a party do not contain requirements on transparency of international investment arbitration. However, the two notable treaties that Viet Nam has recently concluded, the Comprehensive and Progressive Agreement for Trans-Pacific Partnership $(\mathrm{CPTPP})^{3}$ and the EU-Viet Nam Investment Protection Agreement $(\text { EVIPA })^{4}$, have stipulated the procedural transparency requirements, which are in line with a new trend of development in international investment law.

\section{THE EVOLUTION OF TRANSPARENCY REQUIREMENTS IN THE SETTLEMENT OF INVESTOR-STATE DISPUTES}

Nowadays, most investor-state disputes are settled by investment arbitration. Arbitration itself is generally understood as an alternative dispute settlement (ADR) process whereby the parties refer their dispute to an arbitral tribunal for settlement. The most common form of arbitration is commercial arbitration, which handles disputes between private parties to contracts containing arbitration clauses. Meanwhile, investment arbitration is essentially arbitration between an investor and the host state, and typically occurs as a result of investment treaties between the home state of the investor and the host state.

Important characteristics of commercial arbitration include privacy and confidentiality. While these terms are sometimes used interchangeably, generally speaking, privacy means that third parties' access to the proceeding is restricted, and confidentiality refers to the factthat the information about the arbitration, such as its existence, the parties' submission, the tribunal's orders and awards, cannot be disclosed to any non-parties. For commercial arbitration, privacy and confidentiality are often perceived as an advantage compared to traditional litigation, and the legitimacy of these features are often unchallenged as the arbitration is between private parties and concerns their private commercial interests.

As investment arbitration has been developed largely based on the procedural framework for commercial arbitration, it shares certain common features with the latter, including privacy and confidentiality. However, the

International treaties on investment consist of bilateral investment treaties (BIT), and treaty with investment provisions (TIP), the most common of which are free trade agreements. In this article, these treaties are commonly referred to as investment treaties.

Viet Nam signed the Comprehensive and Progressive Agreement for Trans-Pacific Partnership ("CPTPP") on 8 March 2018, ratified it on 12 November 2018. The Agreement has come into effect for Viet Nam since 14 January 2019.

4 The EU and Viet Nam, signed the EVIPA on 30 June 2019. See Joint press statement by Commissioner Malmström and Minister Tran Tuan Anh, https://trade.ec.europa.eu/doclib/ press/index.cfm?id=2041. The text of EVIPA is available at http://trade.ec.europa.eu/doclib/ press/index.cfm?id=1437. Viet Nam ratified the Agreement on 18 June 2020. The European Parliament ratified it on 12 February 2020. The EVIPA will enter into force after the EU member ratification procedures complete. 
lack of transparency in investment arbitrations has been increasingly criticised by commentators, mainly due to the presence of public interests manifested in this type of dispute. ${ }^{5}$ First, as the state itself is a party to the arbitration, the public has a clear interest in learning about the government's pursuit and the outcome of the case, as government activities should be subject to basic requirements of transparency, public participation and accountability. ${ }^{6}$ Second, investment arbitrations involve large monetary claims against the state which is paid out of the state budget if awarded, thus invoking the interest of taxpayers. ${ }^{7}$ Third, many investment arbitrations involve allegations of government misconducts, including those of bribery and corruption, ${ }^{8}$ and the public has a clear interest in and a right to know about these allegations, ${ }^{9}$ which could also be important in deterring such misconducts. Fourth, decisions of the host state on important public policy issues falling under their power to regulateare often challenged in investment arbitrations as violation of investment protection provisions. ${ }^{10}$ Finally, investment arbitrations often concern resources and/or property rights of the public, as most big investment projects which are often the subjects of investment arbitration involve access to natural resources, public infrastructures, and public utilities (e.g. construction of roads, power plants etc.). ${ }^{11}$

In addition to benefiting the public, it has been suggested that increased transparency may bring about certain advantages to the disputing parties as well. For the host state, transparency means that arbitrators must bear in mind that their awards will be subject to public scrutiny. As a result, arbitral tribunals may be more inclined to carefully consider the arguments of host states related to their important public policy measures. Transparency has also been suggested to be helpful in the treaty-making process. ${ }^{12}$ Since arbitral awards in prior arbitration show the interpretation and application by tribunals of treaty provisions, states often take them into account when drafting future treaties. ${ }^{13}$ On the investors' side, it has also been suggested

UNCTAD Series on Issues in International Investment Agreements II, “Transparency”, p. 36. Joint paper by CIEL and IISD (2007), 'Revising UNCITRAL Arbitration Rules to Address Investor-State Arbitrations', p. 4.

Ibid.

For instance, see World Duty Free Company v Republic of Kenya (ICSID Case No. Arb/00/7) Award (4 October 2016); Fraport A G Frankfurt Airport Services Worldwide v. The Republic of the Philippines (ICSID Case No. ARB/03/25) Award (10 December 2014).

$9 \quad$ Joint paper by CIEL and IISD, supra note 6.

10 For instance, see Philip Morris Asia Limited v. The Commonwealth of Australia, UNCITRAL, PCA Case No. 2012-12, Award on Jurisdiction and Admissibility (17 December 2015).

11 Yu H.-L. and Giupponi B. O. (2016), 'The Pandora's Box Effects under the UNCITRAL Transparency Rules', The Journal of Business Law, 2016 (5), p. 352.

12 Calamita N. J. (2014), 'Dispute Settlement Transparency in Europe's Evolving Investment Treaty Policy - Adopting the UNCITRAL Transparency Rules Approach', Journal of World Investment \& Trade, p. 653.

$13 \quad$ Ibid. 
that despite certain disadvantages of transparency, investors might happily accept it in exchange of a fairer and more predictable dispute settlement mechanism, ${ }^{14}$ given that arbitral tribunals may put more effort in ensuring that the contents of their award are consistent with other widely recognized awards. Additionally, the confidentiality of investor-state arbitration may lead to an asymmetrical knowledge among the disputing parties as to, among other things, the viewpoints of arbitrators, and more transparency may assist the parties in appointing arbitrators for their case..$^{15}$

With that said, there are also concerns that lifting the veil of secrecy often brings about negative impacts on the arbitral proceedings for the disputing parties, such as increased cost, delay of proceedings, impaired confidentiality and weaken secrecy of protected information, compromise of procedural integrity, and interference with proceedings. ${ }^{16}$ As a result, along with an increase in transparency, arbitral tribunals and disputing parties may need to adopt appropriate measures to counteract the negative impacts. For example, the potential increase in cost and delay by allowing public access to the proceedings has been addressed in practice by using webcasting. ${ }^{17}$ The threat of disclosure of protected information, such as state secrets and business secrets of investors, can be prevented by redacting them from the documents to be made publicly available. Arbitral tribunals may also try to limit the costs and expenses for the parties by setting out and enforcing strict limits for the non-disputing parties to make their submission.

Given the importance of protecting public interest, nowadays, most commentators believe that the need for transparency is self-evident and crucial for the legitimacy of the investment arbitration regime. ${ }^{18}$ Realizing the need to safeguard the right of their constituents, many states have endeavoured to introduce procedural transparency requirements in resolving investment disputes in their international commitments, including states who used to oppose to such requirements such as China. ${ }^{19}$ While most investment

14 Maupin J. A. (2013), 'Transparency in International Investment Law: The Good, the Bad, and the Murky' in Bianchi A. and Peters A. (eds), Transparency in International Law, Cambridge University Press, p. 160

15 Calamita, supra note 12, p. 652

16 Magraw D. B. and Amerasinghe N. M. (2009), 'Transparency and Public Participation in Investor-State Arbitration', ILSA Journal of International \& Comparative Law, No. 15:2, pp. 352-356.

17 CIEL (2010), Webcasting as a tool to increase transparency in dispute settlement proceeding, p. 6.

18 See e.g. Maupin, supra note 14; Magraw D. B. and Amerasinghe N. M. (2009), 'Transparency and Public Participation in Investor-State Arbitration', ILSA Journal of International E Comparative Law, No. 15:2, p. 349.

19 Malanczuk P. (2015), 'China and the Emerging Standard of Transparency in Investor-State Dispute Settlement (ISDS)', in New Zealand Association for Comparative Law: hors série Vol XIX, 2015. Retrieved from http://www.victoria.ac.nz/law/research/publications/about$\mathrm{nzacl} /$ publications/special-issues/hors-serie-volume-xvi,-2013/Malanczuk.pdf [accessed 15 July 2019], p. 93. 
treaties currently in force do not explicitly deal with procedural transparency in investment arbitration, it is expected that this will become a common characteristic in modern investment treaties.

Over the past years, there has been a global trend toward incorporating more transparency requirements in investment treaties by states and important institutions in the international investment treaties regime, by providing such requirements in the treaties themselves or by amending the arbitration rules to which investment treaties refer.

It is often said that the global movement toward transparency has created four "generations" of procedural transparency rules, consisting of those provided in: (i) the North American Free Trade Agreement ("NAFTA"); (ii) the BITs of NAFTA's member states; (iii) the arbitration rules application to arbitration at the International Centre for Settlement of Investment Disputes ("ICSID"); and (iv) the UNCITRAL Rules on Transparency in Treaty-based Investor-State Arbitration of 2014 (hereinafter "UNCITRAL Transparency Rules"). ${ }^{20}$

Entered into force in January 1994 among the United States, Mexico and Canada, the NAFTA aimed to, among other things, "making economic transactions transparent and secure in the region", and is often seen as a "pioneer" in promoting procedural transparency in treaty making process. ${ }^{21}$ Interestingly, the original text of the treaty only deals with transparency in a limited manner. ${ }^{22}$ It was not until 2001 that the NAFTA Free Trade Commission, whose interpretation of NAFTA is binding, ${ }^{23}$ issued its first Chapter 11 Note of Interpretation which affirmed that there was no presumption of confidentiality in Chapter 11 disputes in relation to the publicity of documents submitted to and issued by the tribunal, ${ }^{24}$ and later in 2003, affirmed that amicus curiae submissions are allowed as well. ${ }^{25}$ Accordingly, in practice NAFTA arbitrations are often regarded as having achieved the highest level of transparency, and NAFTA parties also frequently publish documents related to Chapter 11 arbitrations. ${ }^{26}$

$\overline{20}$ Yu H.-L. and Giupponi B. O., supra note 11, p. 349.

$21 \quad$ Ibid.

22 Articles 1127,1128 , and 1129 of NAFTA only provide that a non-disputing NAFTA state (i.e. not being a party to the arbitration) may (i) receive notice of any arbitration and copies of all pleadings, (ii) make submission on questions of interpretation of NAFTA, and (iii) receive all of evidence presented to the arbitral tribunal as well as the written arguments of the parties. Article 1137.4 further provides that in case the United States or Canada is a disputing party, either the state or the investor may make the award public.

23 Article 1131(2) of NAFTA.

$24 \quad$ NAFTA Free Trade Commission, Notes of Interpretation of Certain Chapter 11 Provisions (31 July 2001), Point A.1.

25 NAFTA Free Trade Commission, Statement of the Free Trade Commission on Nondisputing Party Participation (7 October 2003).

26 Yu H.-L. and Giupponi B. O., supra note 11, p. 349. 
Later on, the United States and Canada have incorporated their experience with transparency requirements under NAFTA in their subsequent treaty making practice. Both the 2004 US Model BIT ${ }^{27}$ and its subsequent 2012 version $^{28}$, and the 2004 Canada Model Foreign Investment Promotion and Protection Agreement ("FIPA") 29 and its subsequent 2014 version, ${ }^{30}$ contain provisions dealing with aspects of transparency, including requiring that the respondent state publish certain documents submitted to and issued by the tribunal, ${ }^{31}$ allowing public access to hearings, ${ }^{32}$ and allowing amicus submissions. ${ }^{33}$ In practice, these transparency requirements have been featured quite consistently in the investment treaties to which the United States or Canada is a party. ${ }^{34}$ The transparency provision in the CPTPP also seems to have been heavily influenced by the same under the 2012 US Model BIT.

The next development in the global practice toward transparency occurred with respect to the arbitration rules governing the arbitral proceedings, in particular the ICSID Arbitration Rules. Established in 1966 by the Convention on the Settlement of Investment Disputes between States and Nationals of Other States ("ICSID Convention"), ICSID is the world's leading institution in resolving investment disputes. ICSID may administer two main types of investment arbitrations: (i) arbitrations between a national of a contracting state to the ICSID Convention and a contracting state, which shall be administered in accordance with the arbitration rules under the ICSID Convention ("ICSID Convention Arbitration Rules"); and (ii) arbitrations between a national of a contracting state and a non-contracting state, or between a national of a non-contracting state and a contracting state, which shall be conducted in accordance with the arbitration rules under the ICSID Additional Facility Rules ("ICSID Additional Facility Arbitration Rules"). Currently, Viet Nam is not a party to the ICSID Convention, but certain investment treaties of Viet Nam have provided for arbitration in accordance with the ICSID Additional Facility Rules. ${ }^{35}$

\footnotetext{
272004 US Model BIT (https://ustr.gov/archive/assets/Trade_Sectors/Investment/Model_ BIT/asset_upload_file847_6897.pdf)

282012 US Model BIT (https://ustr.gov/sites/default/files/BIT\%20text\%20for\%20ACIEP\%20 Meeting.pdf)

292004 Canada FIPA (https://investmentpolicy.unctad.org/international-investment-agreements/ treaty-files/2820/download).

2014 Canada FIPA (https://www.italaw.com/sites/default/files/files/italaw8236.pdf).

Article 29.1 of 2004 US Model BIT; Article 29.1 of 2012 US Model BIT; Article 38.3 of 2004 Canada FIPA; Article 31.1 of 2014 Canada FIPA.

32 Article 29.2 of 2004 US Model BIT; Article 29.2 of 2012 US Model BIT; Article 38.1 of 2004 Canada FIPA; Article 31.2 of 2014 Canada FIPA.

33 Article 28.3 of 2004 US Model BIT; Article 28.3 of 2012 US Model BIT; Article 39 of 2004 Canada FIPA; Article 32 of 2014 Canada FIPA.

Calamita, supra note 12 , pp. 656, 659.

E.g. Article 9.4(b) of the Korea-Viet Nam BIT 2004.
} 
Although proposals to enhance transparency in ICSID arbitrations was discussed as early as 2001, it was not until 2006 that substantive achievements have been made in the amendments to the arbitration rules under both the ICSID Convention and ICSID Additional Facility Rules, which are still applicable as of current. Both these sets of rules allow for submission of amicus curiae brief, ${ }^{36}$ open hearings ${ }^{37}$ and publication of awards with the parties' consent, or excerpts of the legal reasoning of every award even if the parties do not agree. ${ }^{38}$

Finally, the UNCITRAL Transparency Rules was adopted by UNCITRAL on 11 July 2013 as a set of procedural rules supplementing UNCITRAL Arbitration Rules, and came into effect from 1 April, 2014. The UNCITRAL Arbitration Rules is one of the most frequently adopted ad-hoc arbitration rules for investment arbitrations in practice, and is commonly referred to in investment treaties, including those of Viet Nam. However, the UNCITRAL Arbitration Rules was originally designed with commercial arbitration in mind, and thus did not contain express requirements of transparency. The UNCITRAL Working Group II on Arbitration and Conciliation, therefore, was mandated to begin discussions to seek for greater transparency in investor-state arbitration in 2008, the final product of which is now widely known as one of the most comprehensive instruments for transparency.

Regarding its scope of application, the UNCITRAL Transparency Rules automatically applies to (i) all investment arbitrations initiated under UNCITRAL Arbitration Rules and pursuant to investment treaties concluded on or after 1 April, 2014 and that do not exclude its application; or (ii) arbitrations pursuant to investment treaties concluded before such date, if the disputing parties agree to the application of the UNCITRAL Transparency Rules, or if the state parties to the investment treaties prescribe its mandatory application. ${ }^{39}$ The Rules provide for an "automatic and mandatory" 40 publication of several documents such as statements and submissions by the disputing parties or third parties, orders, decisions and awards of the tribunal. ${ }^{41}$ Public hearings are to be held in default, and amicus curiae briefs may be allowed if the tribunal so decides. ${ }^{42}$

\footnotetext{
$36 \quad$ ICSID Convention Arbitration Rules, Rule 37; ICSID Additional Facility Arbitration Rules, Article 41

37 ICSID Convention Arbitration Rules, Rule 32; ICSID Additional Facility Arbitration Rules, Article 39.

38 ICSID Convention Arbitration Rules, Rule 48; ICSID Additional Facility Arbitration Rules, Article 53.

UNCITRAL Transparency Rules, Article 1.

Yu H.-L. and Giupponi B. O., supra note 11, p. 349.

UNCITRAL Transparency Rules Article 3.1.

UNCITRAL Transparency Rules Article 4.1.
} 
The importance of transparency in international investment arbitration is widely recognized, as could be evidenced by Resolution No. 68/109 dated 16 December, 2013 of the United Nation's General Assembly, which recommends that, "subject to any provision in relevant treaties that may require a higher degree of transparency than that provided in the Rules on Transparency, the Rules be applied through appropriate mechanisms to investor-State arbitration initiated pursuant to treaties providing for the protection of investors or investments concluded before the date of coming into effect of the Rules, to the extent that such application is consistent with those treaties." ${ }^{33}$

Afterwards, the United Nations Convention on Transparency in Treaty-based Investor-State Arbitration of 2014 (also known as the "Mauritius Convention on Transparency") has been introduced. ${ }^{44}$ The Convention requires member states to apply the UNCITRAL Transparency Rules to all arbitration cases conducted under an investment treaty concluded before 1 April, $2014^{45}$ between an investor bearing the nationality of a member state and another member state. ${ }^{46}$ This is an attempt to multilateralize the UNCITRAL Transparency Rules, and extend its scope of application to cases before its effective date or cases not conducted in accordance with UNCITRAL Arbitration Rules. ${ }^{47}$ In addition, if an investor of a non-member state bringing a case against a member state of the Convention elects so, the Rules will also apply. ${ }^{48}$ Given the network of thousands of individually negotiated investment treaties between different parties, the Mauritius Convention allows member states to restrict the application of the Convention by making the following reservations: ${ }^{49}$ (i) excluding a specific investment treaty; (ii) excluding the possibility for an investor from a non-member state to elect the UNCITRAL Transparency Rules; and (iii) excluding the application to specific arbitration rules.

$43 \quad$ Resolution adopted by the General Assembly on 16 December 2013 [on the report of the Sixth Committee (A/68/462)] 68/109. United Nations Commission on International Trade Law Rules on Transparency in Treaty-based Investor-State Arbitration and Arbitration Rules (as revised in 2010, with new article 1, paragraph 4, as adopted in 2013). UN Doc. A/ RES/68/109, 18 December 2013. Retrieved from http://www.un.org/en/ga/search/ view_doc.asp?symbol=A/RES/68/109 [accessed 15 July 2019]. The United Nations Convention on Transparency in Treaty-based Investor-State Arbitration (Mauritius Convention on Transparency) was signed on 10 December 2014 and entered into force on 18 October 2017. Article 1(1), Mauritius Convention on Transparency. Article 2(1), Mauritius Convention on Transparency. Ibid.

Article 2(2), Mauritius Convention on Transparency. Article 3(1), Mauritius Convention on Transparency. 
In addition to the multilateralization developments, the transparency provisions are increasingly incorporated into more investment treaties, including the EVIPA and CPTPP, which Viet Nam has recently concluded, such as new requirements on publicity of documents, public hearing and amicus curiae submission.

The next parts of this article will provide an overall introduction to the procedural transparency requirements in investment treaties, and closely examine two recently concluded treaties of Viet Nam which are of great importance because of their coverage of investments from influential partners. These are the EU-Viet Nam Investment Protection Agreement ("EVIPA"), which has been ratified by the European Parliament on 30 March 2020 and by the National Assembly of Viet Nam on 18 June 2020, and the Comprehensive and Progressive Agreement for Trans-Pacific Partnership (“CPTPP”), which has come into effect for Viet Nam since 14 January 2019.

\section{PROCEDURAL TRANSPARENCY REQUIREMENTS FOR INVESTOR-STATE ARBITRATION UNDER INVESTMENT TREATIES}

While it is clear that transparency is a desirable feature in investment arbitration, there is no definition of what constitutes transparency as well as the required extent of transparency that must be provided. As a result, there exist certain inconsistencies in how the issue of transparency is addressed among different procedural rules for investment arbitrations. However, generally speaking, most arbitration procedural rules, including the investment treaties or the arbitral rules referred to by investments treaties, often seek to enhance transparency and public participation by introducing three new features to investment arbitration's proceedings: ${ }^{50}$

(i) public access to documents related to the arbitration;

(ii) public access to hearings; and

(iii) amicus curiae submission.

At their most robust form, the procedural rules related to transparency (hereinafter "transparency clauses") may provide for these features as compulsory requirements, notwithstanding any objection from a party to the arbitration. Regarding the first feature, under transparency clauses, certain documents related to the arbitration, such as written submissions of the parties, the orders, decisions, and awards of the arbitral tribunal, must be made available to the public (subject to certain exceptions), either by the disputing parties or a third party acting as a repository. The second feature compels tribunals to, subject to appropriate logistical arrangements

$50 \quad$ Nuemann T. and Simma B. (2013), 'Transparency in International Adjudication', in Bianchi A. and Peters A. (eds), Transparency in International Law, Cambridge University Press, pp. 436- 437. 
and certain exceptions, conduct the hearings open to the public. Through these requirements, transparency clauses aim to enhance public awareness and oversight of the arbitration.

The third feature often authorizes the tribunals, subject to appropriate safeguards to ensure the integrity of the proceedings, to allow submissions made by non-disputing parties on matters within the scope of the arbitration. This is a novel feature since the participation of third parties in "traditional" commercial arbitration, in most cases, must receive the consent of the disputing parties. Under this rule, stakeholders other than the investors and the host states whose interest might be affected by the outcome of the arbitration may furnish the tribunals with information influencing their decisions. Among those stakeholders who most frequently submit amicus briefs to international investment tribunals are non-governmental organizations, whose specific focus is often on the environmental or human rights aspects of the dispute. ${ }^{51}$ There are also a variety of other non-party stakeholders who may have an interest in the proceedings and wish to submit their opinions, including governmental organizations, ${ }^{52}$ indigenous communities where the claimant's properties are located, ${ }^{53}$ or industry groups and other individuals. ${ }^{54}$

Generally speaking, in addition to introducing more transparency requirements, transparency clauses often contain exceptions to maintain a balance between the public interest on the one hand, and the interest of the disputing parties on the other hand in the fair and efficient resolution of the dispute. All treaties containing transparency clauses to which Viet Nam is a party, with slight variations, provide for rather similar exceptions concerning: confidential business information, ${ }^{55}$ information protected against being made public under the treaty or under the law of the respondent state, or any other applicable laws; ${ }^{56}$ information whose disclosure would be contrary to the essential security interests of a respondent state, ${ }^{57}$ or would impede law enforcement. ${ }^{58}$ While these exceptions were created to safeguard important

\footnotetext{
$51 \quad$ See, generally, Ishikawa T. (2010), 'Third Party Participation in Investment Treaty Arbitration', International and Comparative Law Quarterly, 39, pp. 378-388.

52 See, e.g.: Micula (and others) v. Romania (ICSID Case No. ARB/05/20); Philip Morris Brands SARL and others $v$. Republic of Uruguay (ICSID Case No. ARB/10/7).

53 See, e.g.: Bernhard von Pezold and Others v. Republic of Zimbabwe (ICSID Case No. ARB/10/15).

54 See, e.g.: Eli Lilly and Company v. Canada (ICSID Case No. UNCT/14/2)

55 UNCITRAL Transparency Rules, Article 7.2; CPTPP, Article 29.7.

56 Ibid. The EVIPA, while adopting this approach in its entirety, also added an exception related to classified government information, which presumably, absent a clear definition in the EVIPA, includes any information that the government determines to be classified in accordance with applicable regulations.

57 UNCITRAL Transparency Rules, Article 7.5; CPTPP, Article 29.2.

58 UNCITRAL Transparency Rules, Article 7.2; CPTPP, Article 29.7
} 
and legitimate interests, the exception regarding information protected under the law of the respondent state can be considered as a limitation of the transparency clauses due to its potential abuse.

Under this exception, a tribunal applying the transparency requirements cannot use its discretion, but must grant protection to any documents designated as such by the respondent state under its law (although the tribunal is still the interpreting authority of the domestic law). ${ }^{59}$ This approach carry some weight, as unlike the investor, who is mostly concerned with the disclosure of trade secrets or other confidential business information, the disclosure of information if conducted in a careless and unselective manner is a big concern for any sovereign power. The fact that the law of the respondent state is applied means that the respondent state has more flexibility and control over the disclosure of documents, and is not put in an undesirable position of having to violate its own law, resulting in somewhat greater consistency between international and domestic laws. ${ }^{60}$ Therefore, it is understandable and quite reasonable to give weight to information protected under the law of the respondent state.

On the other hand, this degree of control also allows a respondent state, who wishes to keep certain documents from being publicized for reasons against the purpose of transparency, to do so by classifying them as protected information under its law. This was a threat felt by the drafters of the UNCITRAL Transparency Rules, who initially wanted the decision on the exception to transparency to be made by the tribunal without the respondent state's influence, ${ }^{61}$ as this would "permit a state to circumvent the object of the Rules by introducing legislation precluding the disclosure of all information in investor-State disputes". ${ }^{2}$ However, the need to account for the respondent state's law was pushed rigorously by many states at the negotiations, and this exception made its way into the final text of the UNCITRAL Transparency Rules.

It is often believed that in a well-developed system of access to government information, this issue does not pose much of a threat to transparency, as there are often effective domestic remedies under these systems when the government went too far to protect confidentiality. ${ }^{63}$

\footnotetext{
$59 \quad$ Euler D. et al. (eds.) (2015), Transparency in International Investment Arbitration: A Guide to the UNCITRAL Rules on Transparency in Treaty-Based Investor-State Arbitration, CUP, p. 271.

60 UNCITRAL, 'Report of Working Group II (Arbitration and Conciliation) on the work of its fifty-seventh session', UN Doc. A/CN.9/760, 12 October 2012, 102.

61 UNCITRAL, 'Report of Working Group II (Arbitration and Conciliation) on the work of its fifty-third session', UN Doc. A/CN.9/712, 20 Oct 2010, 69

62 UNCITRAL, 'Report of Working Group II (Arbitration and Conciliation) on the work of its fifty-seventh session', UN Doc. A/CN.9/760, 12 October 2012, 103.

63 Laird I. A. (2014), 'Transparency in investor-state arbitration', OUP blog. Retrieved from https:// blog.oup.com/2014/03/transparency-in-investor-state-arbitration/ [accessed 9 May 2017].
} 
At present, the public access to government documents in Viet Nam is mainly governed by the Law on Access to Information of 2016, which regulates the right to information in general, ${ }^{64}$ and the Law on State Secrets Protection of $2018 .{ }^{65}$ Both the Law on Access to Information 2016 and the Law on State Secrets Protection 2018 can serve as a basis for refusing to disclose documents related to investment arbitrations. Under these legal instruments, the public cannot access state's secrets and several general categories of information, the most relevant to investment arbitration include information "whose disclosure will impair the state interest", or "work secrets" or "documents prepared by state agencies for its internal work". ${ }^{66}$ However, where Viet Nam has accepted transparency obligations under treaties, pursuant to its principle that treaties shall prevail over conflicting domestic laws, ${ }^{67}$ the compliance with transparency obligations will need to be secured with regard to documents to be disclosed. Exceptions to these requirements are only applicable to particular types of information as discussed above and will not create a bar to the access to documents related to arbitration in their entirety.

It is also worth mentioning that it was unanimously determined by the drafters of the UNCITRAL Transparency Rules that a state who has adopted the Rules cannot "use its domestic law to undermine the spirit (or the letter) of such rules." ${ }^{\prime \prime 8}$ In such a case, in accordance with Article 1.6 of the Rules, the arbitral tribunal is authorized to ensure that the transparency objectives be realized, by, e.g. bypassing the domestic laws, "in the presence of any conduct, measure or other action having the effect of wholly undermining these objectives". ${ }^{69}$

\section{TRANSPARENCY FOR THESETTLEMENT OFINVESTOR- STATE DISPUTES UNDER EUROPEAN UNION - VIET NAM INVESTMENT PROTECTION AGREEMENT}

The EVIPA explicitly provides that the UNCITRAL Transparency Rules shall automatically apply in all arbitrations regardless of their arbitration rules, subject to a few mostly related to the disclosure of documents in connection with the dispute. ${ }^{70}$ Notably, apart from documents listed under Article 3 of

\footnotetext{
64 Law No. 104/2016/QH13 on Access to Information dated 6 April 2016, which came into effect from 1 July 2018 (hereinafter "Law on Access to Information 2016").

65 Law No. 29/2018/QH14 on protection of State Secrets dated 15 January 2018, which came into effect from 1 July 2020 (hereinafter "Law on State Secrets Protection 2018”). Ibid, Article 6.

Art. 6(1) of Law No. 108/2016/QH13 on Treaties dated 9 April 2016.

UN Doc. A/CN.9/760, supra note 90, at 103; UNCITRAL, Report of Working Group II (Arbitration and Conciliation) on the work of its fifty-eighth session, UN Doc. A/CN.9/765, 13 February 2013, p. 65.

UNCITRAL Transparency Rules, Article 1.6.

EVIPA, Article 3.46(1).
} 
the UNCITRAL Transparency Rules, it compels the disclosure of several documents specific to the dispute resolution mechanism under the EVIPA (such as those related to the special appellate investment tribunal mechanism). ${ }^{71}$

Similar to other treaties incorporating the UNCITRAL Transparency Rules, the only obligations imposed by the EVIPA on the respondent state relate to the disclosure to the public about the existence of the arbitration. ${ }^{72}$ In accordance with Article 2 of the UNCITRAL Transparency Rules, once the respondent state receives the notice of arbitration from the investor, the investor and the respondent state are obliged to provide a copy of that notice to the repository of published information under the UNCITRAL Transparency Rules, which is the Transparency Registry at the United Nations in Vienna. ${ }^{73}$ After this notice of arbitration is sent to the repository, the repository will be in charge of publishing certain information about the arbitration at its commencement, namely the name of the disputing parties, the economic sector involved and the treaty under which the claim is being made. ${ }^{74}$

What happens if the respondent state and the investor fail to fulfil their obligation to send the notice of arbitration to the repository? This scenario is likely to happen since there are already many incentives for the disputing parties to conceal, or at least delay, the disclosure of the existence of their dispute, unless there is a sufficiently severe sanction for doing so.

In this regard, nowhere in the UNCITRAL Transparency Rules or the EVIPA can a sanction for the non-compliance with transparency obligations be found. Such an issue was raised before by the drafters of the UNCITRAL Transparency Rules, who considered it "a difficult matter to address in an instrument of the nature of the rules". ${ }^{75}$ However, Article 1.6 of the Rules also provides that the arbitral tribunal shall ensure that objectives of transparency prevail in presence of conducts undermining them. As a result, although at the time of the notice of arbitration the tribunal was not constituted yet, if both disputing parties fail to send the notice of arbitration, the tribunal can react to such failure after it is constituted by communicating a copy of that notice directly to the repository, and order it to publish the name of the disputing parties, the economic sector involved, and the treaty under which the claim is made. ${ }^{76}$ The Guidelines circulated by the Transparency Registry also provide that "the arbitral tribunal shall also submit the notice of arbitration to the Registry, if the disputing parties

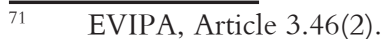

Euler D. et al. (eds.), supra note 59, p. 324.

UNCITRAL Transparency Rules, Article 2.

UNCITRAL Transparency Rules, Article 2.

UNCITRAL, 'Report of Working Group II (Arbitration and Conciliation) on the work of its fifty-fifth session', UN Doc. A/CN.9/736, 3-7 October 2011, p. 45.

Euler D. et al. (eds.) (2015), supra note 59, p. 79.
} 
have failed to do so". ${ }^{77}$ Therefore, the final objective of this obligation, which is making the public aware of the existence of the dispute, would still be achieved, albeit not as promptly as intended by the Rules. ${ }^{78}$

For documents other than the notice of arbitration, the UNCITRAL Transparency Rules impose the duty of disclosure not on the disputing parties, but on the tribunal, who must communicate these documents to the repository as soon as possible, ${ }^{79}$ and the repository, who must ensure that the documents sent to it by the tribunal are made available to the public timely. ${ }^{80}$ Thus, there should be no hindrance to transparency posed by the parties' non-compliance in this regard.

TheEVIPA, while incorporating these provisions, also imposes additional disclosure duties on the respondent state to make publicly available a number of additional documents specific to the dispute resolution mechanism under the EVIPA, including the request for consultation, notice of intent to submit a claim, notice of determination (only in case the respondent is the EU), notice of challenge and decision on challenge to members of the tribunal (including those of the appeal tribunal), and the request for consolidation of disputes. ${ }^{81}$ The respondent state can choose to make publicly available these documents by sending to the UNCITRAL Transparency Repository or otherwise, including publishing them by itself. ${ }^{82}$ Nevertheless, as the arbitral tribunal is also mandated to submit these documents to the repository, ${ }^{83}$ this obligation of the respondent state is complementary in nature; failure to perform does not render the objective of transparency unachievable.

In conclusion, the EVIPA, which incorporates the UNCITRAL Transparency Rules, has ensured the achievement of transparency by imposing the obligations on disclosing documents (other than the notice of arbitration) on the respondent state, the tribunal, and the repository (i.e. the Transparency Registry). With respect to the disclosure of the notice of arbitration at the early stage where the arbitral tribunal has not been incorporated, this belongs to the obligation of the disputing parties. If the disputing parties do not comply with this obligation, after being established the arbitral tribunal may also coordinate with the Transparency Registry to publish the notice of arbitration.

\footnotetext{
77 Guidelines of the UNICTRAL Transparency Registry, Article D(2). Retrieved from http:// www.uncitral.org/transparency-registry/en/guidelines.html [accessed 11 May 2017].

Euler D. et al. (eds.) (2015), supra note 59, p. 79.

UNCITRAL Transparency Rules, Article 3.3.

UNCITRAL Transparency Rules, Article 3.

EVIPA, Article 3.46(4).

EVIPA, Article 3.46(4) and Article 3.46(5).

Article 3.46(2) of EVIPA incorporates these additional documents into the list of documents to be communicated by the tribunal pursuant to Article 3.4 of the UNCITRAL Transparency Rules.
} 


\section{TRANSPARENCY IN INVESTOR-STATE ARBITRATION UNDER THE CPTPP}

The CPTPP is a FTA concluded among 11 member states, ${ }^{84}$ with a wide coverage of trade and non-trade matters and high level of commitments. Pursuant to the requirements of the treaty, all arbitral hearings must be conducted publicly ${ }^{85}$ a number of documents must be published from the initiation of the arbitration until the arbitral award is issued, ${ }^{86}$ and the arbitral tribunal can decide to accept amicus curiae briefs. ${ }^{87}$

However, unlike the EVIPA, the CPTPP does not really have an effective mechanism to ensure compliance with transparency requirements. As opposed to the UNCITRAL Transparency Rules which imposes most of document disclosure obligation on the arbitral tribunal and the registry, the CPTPP imposes the obligation on disclosing all documents on the respondent state..$^{88}$ As a result, how the public may access the documents in case the respondent state fails to comply with its obligation can be an issue.

This is a question which is not answered by the CPTPP. Unlike the UNCITRAL Transparency Rules, which empower the tribunal to take measures to ensure the objectives of transparency against the non-compliance of the respondent state, the CPTPP does not provide any guidance on what the tribunal can do in such a case. As the authority of the tribunal stems from the procedural rules as agreed by the disputing parties, absent any authorization, it is unclear whether the tribunal can take necessary measures to ensure the publication of documents. In case the tribunal elects to do so, would that be considered an ultra vires act on the part of the tribunal, whose mandate is only to ensure the prompt resolution of the dispute and the fairness of the proceedings?

Nevertheless, even presuming that the tribunal has the authority to make use of all available means to ensure the publication of the documents related to the proceedings, what means can it employ? The first feasible option is imposing negative consequences following the breach in order to bring the respondent state into compliance with the tribunal's order, which is a controversial issue. ${ }^{89}$ Most arbitration rules are silent on the issue of the sanctioning power of the tribunal, although they often speak of the authority of the tribunal to allocate the costs and fees of the

\footnotetext{
84 Australia, Brunei Darussalam, Canada, Chile, Japan, Malaysia, Mexico, New Zealand, Peru, Singapore and Viet Nam. The CPTPP entered into force on 30 December 2018 and for Viet Nam on 14 January 2019.

CPTPP, Chapter 9, Article 9.24.2.

CPTPP, Chapter 9, Article 9.24.1.

CPTPP, Chapter 9, Article 9.23.3.

CPTPP, Chapter 9, Article 9.21.1.

Euler D. et al. (eds.) (2015), supra note 59, p. 303
} 
arbitration. ${ }^{90}$ Therefore, one common solution is using the decisions on the costs of the arbitration as a mean of sanction. For example, in Pope $\&$ Talbot $v$. Canada, the tribunal has apportioned the costs against Canada for its breaches of confidentiality obligations. ${ }^{91}$ Nevertheless, it is doubtful whether this approach toward breaches of confidentiality obligations can be taken with respect to breaches of transparency obligations. Confidentiality obligations are owed by a disputing party toward the other, whose breaches can undermine the integrity of the arbitral proceedings. In contrast, the obligation to disclose documents related to the proceedings in the CPTPP is not a commitment made toward the investor, but rather a unilateral commitment of the respondent state benefiting its constituents, the breaches of which do not impair, if not benefit the other disputing party's interest i.e. in the confidentiality of the proceedings. Making the investor benefit from the violation of such a commitment seems unreasonable and unjust. More importantly, the decision on cost is often rendered at the finality of the proceedings, which would leave the objectives of giving the public awareness and oversight unobtainable.

Another option is that the tribunal elects to disclose the documents on its own initiative. As an international tribunal is often not well-equipped to handle the publication of documents by itself, it is likely that the tribunal will appoint a third-party repository, such as the UNCITRAL Transparency Registry. In such a case, the tribunal might also apportion the cost of publications against the respondent state, who has breached its obligation in the first place, although such a decision is likely to be challenged at the enforcement stage. However, it is unclear whether any repository will accept such appointment, in absence of the consent from one disputing party. For example, the guidelines provided by the UNCITRAL Transparency Registry indicate that it will only act as a repository if appointed by parties to the arbitration themselves. ${ }^{92}$

With respect to exception, Article 29.7 of the CPTPP clearly stipulates that "nothing in [the CPTPP] shall be construed to require a Party to furnish or allow access to information, the disclosure of which would be contrary to its law...]". This creates greater discretion for the respondent state in restricting the treaty's transparency requirements, which is different from the UNCITRAL Transparency Rules, which allows the arbitral tribunal to make the decision.

90 McGowan G. V., 'Sanctions in US and International Arbitrations: Old Law In Modern Context', Kluwer Arbitration Blog. Retrieved from http://kluwerarbitrationblog.com/2013/10/10/sanctionsin-us-and-international-arbitrations-old-law-in-modern-context/ [accessed 9 May 2020].

91 Pope \& Talbot Inc. v. The Government of Canada, UNCITRAL, Award in Respect of Costs (26 Nov 2002) [11]-[13].

92 UNCITRAL Transparency Registry, 'Introduction'. Retrieved from http://www. uncitral.org/transparency-registry/en/introduction.html [accessed 22 June 2020]. 
Overall, introducing requirements of transparency of investor-state arbitration is a new development of international law on investment. This development has also been reflected in the two treaties with major partners that Viet Nam has been and is in the processing of signing recently the CPTPP and the EVIPA. While the approach of EVIPA is to incorporate the UNCITRAL Transparency Rules, the CPTPP provides for its own transparency provisions. Although even now Viet Nam maintains its position on confidentiality for its investor-state arbitration, ${ }^{93}$ Viet Nam has made international commitments on transparency. This is expected to bring the benefits associated with these commitments such as increasing public interest protection, improving governance and ensuring the right to information. Being an UNCITRAL member Viet Nam can contribute to efforts of reforming ISDS, including transparency as an important topic, which opens a door for self-reform in its management of ISDS.

\section{References}

\section{Case law}

[1] Micula (and others) v. Romania (ICSID Case No. ARB/05/20)

[2] World Duty Free Company $v$ Republic of Kenya (ICSID Case No. Arb/00/7) Award (4 October 2016)

[3] Philip Morris Asia Limited v. The Commonwealth of Australia, UNCITRAL, PCA Case No. 2012-12, Award on Jurisdiction and Admissibility (17 December 2015)

[4] Fraport AG Frankfurt Airport Services Worldwide v. The Republic of the Philippines (ICSID Case No. ARB/03/25) Award (10 December 2014)

[5] Eli Lilly and Company v. Canada (ICSID Case No. UNCT/14/2)

[6] Philip Morris Brands SARL and others v. Republic of Uruguay (ICSID Case No. $\mathrm{ARB} / 10 / 7)$

[7] Bernhard von Pezold and Others v. Republic of Zimbabwe (ICSID Case No. ARB/10/15)

[8] Pope \& Talbot Inc. v. The Government of Canada, UNCITRAL, Award in Respect of Costs (26 Nov 2002) [11]-[13]

\section{Books}

[9] Bianchi A. and Peters A. (eds) (2013), Transparency in International Law, Cambridge University Press, p. 160

[10] Euler D. et al. (eds.) (2015), Transparency in International Investment Arbitration: A Guide to the UNCITRAL Rules on Transparency in Treaty-Based Investor-State Arbitration, Cambridge University Press, p.79, p. 324

[11] Nuemann T. and Simma B. (2013), 'Transparency in International Adjudication', in Bianchi A. and Peters A. (eds), Transparency in International Law, Cambridge University Press, pp. 436- 437

\footnotetext{
93 Article 3.2 of the Regulations attached to Decision No. 14/2020/QD-TTg of the Prime Minister dated 8 April 2020 on regulating the coordination between the Vietnamese state bodies in international investment dispute settlement provides that "[p]residing authorities, Government's legal representative body and relevant organizations and individuals shall keep state secrets and maintain confidentiality of information and documents collected during the resolution of international investment disputes in accordance with regulations on international arbitration proceedings and Vietnamese laws."
} 


\section{Working Papers/Reports}

[12] CIEL (2010), Webcasting as a tool to increase transparency in dispute settlement proceeding, p. 6

[13] CIEL and IISD (2007), 'Revising UNCITRAL Arbitration Rules to Address Investor-State Arbitrations', p. 4

[14] UNCITRAL, 'Report of Working Group II (Arbitration and Conciliation) on the work of its fifty-seventh session', UN Doc. A/CN.9/760, 12 October 2012, 102

[15] UNCITRAL, 'Report of Working Group II (Arbitration and Conciliation) on the work of its fifty-fifth session', UN Doc. A/CN.9/736, 3-7 October 2011, p. 45

[16] UNCITRAL, 'Report of Working Group II (Arbitration and Conciliation) on the work of its fifty-third session', UN Doc. A/CN.9/712, 20 Oct 2010, 69

\section{Journal articles}

[12] Calamita N. J. (2014), 'Dispute Settlement Transparency in Europe's Evolving Investment Treaty Policy - Adopting the UNCITRAL Transparency Rules Approach', Journal of World Investment E Trade, pp. 652-653, p.656, p.659.

[15] Ishikawa T. (2010), 'Third Party Participation in Investment Treaty Arbitration', International and Comparative Law Quarterly, 39, pp. 378-388.

[17] Magraw D. B. and Amerasinghe N. M. (2009), 'Transparency and Public Participation in Investor-State Arbitration', ILSA Journal of International \& Comparative Law, No. 15:2, p.349, pp. 352-356

[18] Malanczuk P. (2015), 'China and the Emerging Standard of Transparency in Investor-State Dispute Settlement (ISDS)', in New Zealand Association for Comparative Law: hors série Vol XIX, 2015. Retrieved from http://www.victoria.ac.nz/law/ research/publications/about-nzacl/publications/special-issues/hors-serie-volumexvi,-2013/Malanczuk.pdf [accessed 15 July 2019], p. 93

[25] Yu H.-L. and Giupponi B. O. (2016), 'The Pandora's Box Effects under the UNCITRAL Transparency Rules', The Journal of Business Law, 2016 (5), p. 349, p. 352

\section{Others}

[14] Guidelines of the UNICTRAL Transparency Registry, Article D(2). Retrieved from http://www.uncitral.org/transparency-registry/en/guidelines.html [accessed 11 May 2017]

[16] Laird I. A. (2014), 'Transparency in investor-state arbitration', OUP blog. Retrieved from https://blog.oup.com/2014/03/transparency-in-investor-state-arbitration/ [accessed 9 May 2017]

[19] McGowan G. V., 'Sanctions in US and International Arbitrations: Old Law In Modern Context', Kluwer Arbitration Blog. Retrieved from http://kluwerarbitrationblog. com/2013/10/10/sanctions-in-us-and-international-arbitrations-old-law-inmodern-context/ [accessed 9 May 2020]

[17] Resolution adopted by the General Assembly on 16 December 2013 [on the report of the Sixth Committee (A/68/462)] 68/109. United Nations Commission on International Trade Law Rules on Transparency in Treaty-based Investor-State Arbitration and Arbitration Rules (as revised in 2010, with new article 1, paragraph 4, as adopted in 2013). UN Doc. A/RES/68/109, 18 December 2013. Retrieved from http://www.un.org/en/ga/search/view_doc.asp?symbol=A/RES/68/109 [accessed 15 July 2019]

[20] UNCITRAL Transparency Registry, 'Introduction'. Retrieved from http://www. uncitral.org/transparency-registry/en/introduction.html [accessed 22 June 2020] 